IZA DP No. 990

Generational Accounting as a Tool to Assess Fiscal Sustainability: An Overview of the Methodology

Holger Bonin

Concepció Patxot

J anuary 2004 


\title{
Generational Accounting as a Tool to Assess Fiscal Sustainability: An Overview of the Methodology
}

\author{
Holger Bonin \\ IZA Bonn \\ Concepció Patxot \\ University of Barcelona \\ Discussion Paper No. 990
January 2004 \\ IZA \\ P.O. Box 7240 \\ D-53072 Bonn \\ Germany \\ Tel.: +49-228-3894-0 \\ Fax: +49-228-3894-210 \\ Email: iza@iza.org
}

This Discussion Paper is issued within the framework of IZA's research area General Labor Economics. Any opinions expressed here are those of the author(s) and not those of the institute. Research disseminated by IZA may include views on policy, but the institute itself takes no institutional policy positions.

The Institute for the Study of Labor (IZA) in Bonn is a local and virtual international research center and a place of communication between science, politics and business. IZA is an independent, nonprofit limited liability company (Gesellschaft mit beschränkter Haftung) supported by Deutsche Post World Net. The center is associated with the University of Bonn and offers a stimulating research environment through its research networks, research support, and visitors and doctoral programs. IZA engages in (i) original and internationally competitive research in all fields of labor economics, (ii) development of policy concepts, and (iii) dissemination of research results and concepts to the interested public. The current research program deals with (1) mobility and flexibility of labor, (2) internationalization of labor markets, (3) welfare state and labor market, (4) labor markets in transition countries, (5) the future of labor, (6) evaluation of labor market policies and projects and (7) general labor economics.

IZA Discussion Papers often represent preliminary work and are circulated to encourage discussion. Citation of such a paper should account for its provisional character. A revised version may be available on the IZA website (www.iza.org) or directly from the author. 
IZA Discussion Paper No. 990 January 2004

\section{ABSTRACT \\ Generational Accounting as a Tool to Assess Fiscal Sustainability: An Overview of the Methodology}

The paper surveys the methodology of generational accounting, a tool for gauging intertemporal imbalance in government finances facing demographic transition. Starting from the fiscal balance rule providing the theoretical background, we review the methods of generational accountants for generating empirical projections of the items building up to the intertemporal government budget. We debate indication of generational redistribution by lifetime expected net tax payments and several indicators for fiscal sustainability found in the literature. Finally, the performance of generational accounts, which ignore behavioral and policy dynamics, is compared with that of generational welfare indicators based on overlapping generations general equilibrium models.

JEL Classification: H61, E62, B41

Keywords: generational accounting, fiscal sustainability, methodology, survey

Corresponding author:

Holger Bonin

IZA

P.O. Box 7240

53072 Bonn

Germany

Email: bonin@iza.org 


\section{Introduction}

The purpose of this paper is to provide a survey of the generational accounting procedure, a commonplace instrument for assessing the impact of government fiscal performance over the long term. Examining the impact of fiscal policy, and government deficits in particular, on economic agents indeed requires a forward-looking perspective. Firstly, it is important to assess the viability of government's current financing and spending decisions in the future when economic conditions might change. Conventional indicators of fiscal activity like the annual government (primary) deficit or surplus ignore that much public revenue and spending heavily depends not only on the business cycle, but as well on medium-term and long-term economic forces. In particular, in most of the developed world, demographic shocks are a major challenge for the sustainability of government finances in the long run. ${ }^{1}$ If future levels of taxation do have to increase in order to pay for financial commitments entered into by today's political decision makers, the likely result is inter- and/or intragenerational redistribution - that public debt eventually turns into a burden at least on some economic agents, is a generally accepted view among economists ever since the seminal work of Buchanan (1958) and Modigliani (1961). ${ }^{2}$

Besides, short-term oriented budget indicators are not very informative for gauging whether fiscal policy is actually expansive or not. In the neoclassical framework of rational agents optimizing over a life-cycle consumption plan, decisions are generally disconnected from short-term deficits or surpluses; see the fundamental studies by Summers (1981), Chamley (1981) and Kotlikoff (1979), among others. In fact, fiscal policies that generate identical sequences of reported budget balances by period, might impact very differently on capital formation, and hence economic growth. This prompted Kotlikoff (1988) to a charge against conventional deficit budgeting for arbitrariness that lead to the development of generational accounting as a tool for fiscal policy analysis (Auerbach et al. 1991, 1994).

Generational accounting (GA) rationalizes on the intertemporal budget deficit as the aggregate of the present value of current and future primary deficits, associated with present fiscal policy decisions made by the government. The advantage of this benchmark is that it matches the intertemporal perspective of economic agents as life-cycle planners.

\footnotetext{
${ }^{1}$ See recent studies published by the OECD (Dang et al. 2001) and the European Commission (2001).

${ }^{2}$ See Blejer and Cheasty (1991) for a survey of traditional deficit indicators. Feldstein (1974) puts forward an early critique of short-term budgeting focused on omission of unfunded Social Security liabilities.
} 
To stress this connection, GA results are frequently reported in terms of life-cycle tax burdens evaluated at the level of the individual, representative agent. In this respect, the method clearly differs from other indicators for long-term oriented fiscal sustainability analysis, proposed, for example, by Chouraqui et al. (1990) and Gramlich (1990). ${ }^{3}$

GA is also somewhat different from the set of long-term fiscal indicators Blanchard (1990) developed for the OECD (1998), which also start from the notion that fiscal policy must satisfy an intertemporal budget constraint. Compared with GA, the OECD approach of evaluating the aggregate future primary deficit appears less informative, as it refrains from integrating the impact of fiscal policy at the individual level. More importantly, the adaptation of the intertemporal budget concept by the OECD is inconsistent, as the forecasting is limited to some arbitrary period (of around 50 years), which is too short for discounting neutralizing deficits or surpluses that would occur afterwards. As a consequence, the OECD indicators need to rely on discretionary debt targets reached in the terminal year of the forecast, which are open to criticism. Nevertheless, it should be stressed that the OECD approach is basically a stripped-down version of GA which at the macro level would lead to an identical measure of the gap in the intertemporal government budget, if the forecasting procedure was expanded to an infinite horizon.

The precise theoretical background of GA is to be found in overlapping generations, general equilibrium models (OLG-GE), the dynamic neoclassical model best suited to approaching population economic issues. Combining the life-cycle hypothesis of rational intertemporal decision-making with the interactions between generations, these models make it possible to study the impact of a changing demographic environment on the economy. In this context one can analyze the effects of demographic changes on savings and capital accumulation, the interaction of those key economic variables with public policy and the resulting welfare effects.

GA sacrifices some of the general equilibrium aspects of these models in order to gain applicability and focuses strictly on the demographic impact on the public budget. In particular, it maintains the original age and gender incidence of tax payments and

\footnotetext{
${ }^{3}$ See Gokhale and Smetters (2003) and Balassone and Franco (2001) for reviews of forward-looking budgeting methods. An alternative strand of the literature uses econometric analysis of past behavior of budget aggregates. In general, it seems questionable that a backward-looking approaches is suited to obtain informative results about the long-term future when major structural breaks, such as demographic transition, are likely to be a relevant phenomenon.
} 
transfers receipts and projects it into the future using demographic forecasts. As a result the evolution of government budget in each future year can be extrapolated and thereby the extent to which its meets the intertemporal budget constraint. Hence, while keeping some of the dynamic developments in the economy, GA eliminates the possible response of agents to economic evolution and government policy, which in turns implies constant factor prices. This could seem an extreme simplification but the alternative use of OLGGE models has also its drawbacks. We will come back to the possible bias of GA results due to ignorance of general equilibrium effects at the end of our survey, after introducing the static GA procedure.

The remainder of the paper is organized as follows. The following section provides a more formal introduction to the paradigmatic background of GA. Section 3 discusses the evaluation of generational accounts as the starting the point of the method. Section 4 describes the intertemporal budget constraint connecting current and future fiscal policy. Section 5 combines the results of the previous sections to derive several measures for intertemporal fiscal imbalance found in the GA literature. Finally, as a way of conclusion, Section 6 discusses GA against the background of OLG-GE models.

\section{The Fiscal Balance Rule}

GA rests on the paradigm that government debt in general leads to redistribution across generations. Intergenerational redistribution is defined to be a situation where fiscal policy expands consumption opportunities of one generation at the expense of consumption opportunities of some other generation. Interpretation of public debt as a device of intergenerational redistribution requires a framework for measuring the distributional stance of fiscal policy. Kotlikoff (1993) states an appropriate benchmark for generationally neutral policy in an OLG-GE framework - the fiscal balance rule.

Consider a two-period overlapping generations model a la Diamond (1965), in which population grows at a rate $n$. Young agents spend their labor income $w_{t}$ in consumption $c_{t}^{1}$ and savings $s_{t}$. Old agents do not work. Their consumption $c_{t+1}^{2}$ is financed from past past savings, which create a return $r_{t+1}$. Furthermore assume that the government levies taxes and pays benefits at each stage of the life cycle, and let $m_{t}^{1}$ represent the net tax payments, i.e. the tax payments net of transfers received, during youth and $m_{t+1}^{2}$ net tax 
payments during retirement. The representative agent of each generation maximizes the lifetime utility function

$$
U=U\left(c_{t}^{1}, c_{t+1}^{2}\right)
$$

subject to the intertemporal budget constraint

$$
c_{t}^{1}+\frac{c_{t+1}^{2}}{1+r_{t+1}}=w_{i}-\left[m_{t}^{1}+\frac{m_{t+1}^{2}}{1+r_{t+1}}\right] .
$$

The solution to the optimization problem is given by the set of demand functions

$$
\begin{aligned}
c_{t}^{1} & =c_{t}^{1}\left(w_{t}, r_{t+1}, m_{t}\right) \\
c_{t+1}^{2} & =c_{t+1}^{2}\left(w_{i}, r_{i+1}, m_{t}\right) \\
s_{t}^{1} & =s_{t}^{1}\left(w_{t}, r_{t+1}, m_{t}, a\right)
\end{aligned}
$$

where we introduce $m_{t}=m_{t}^{1}+\frac{m_{t+1}^{2}}{1+r_{t+1}}$ to denote the present value of life-cycle net tax payments characterizing fiscal policy, and the parameter $\mu=\frac{m_{t}^{1}}{m_{t}}$ as a summarizing measure for the relative timing of net tax burdens over the life-cycle.

This simple model suffices to illustrate that agents adapt their consumption precisions to the present value aggregate of life-cycle net tax burdens. Supposed wages and interest rates remain unchanged, the optimal relative consumption profile does not depend on how the government distributes the net tax payment over time. Consequently, the period deficit or surplus associated with a given tax and transfer policy is not a good indicator for agents' potential responses to the policy.

Nevertheless, in general, the timing of tax and transfer payments will affect the equilibrium returns to labor and capital, since it affects capital formation in the economy via savings. Ceteris paribus, if $\mu$ converges to zero, i.e. if net tax payments are concentrated on the elderly, savings increase. Agents wishing to maintain their original life cycle consumption plan save more to finance net tax payments during retirement. For example, in the extreme case that $\mu=0$, savings increase by exactly the amount of the net tax payable when old, which guarantees that the agents can maintain their life-cycle consumption profile independent of the size of the government sector. Likewise, savings decrease when the burden of net taxation shifts to a younger age. In effect, for a given size of the government sector $m_{t}$, equilibrium wages and interest rates will be a function of $\mu$, because optimal savings are. From the macroeconomic perspective, it is therefore crucial to analyze the relative generational distribution of lifetime net tax payments, which again is not reflected by conventional short-sighted fiscal policy indicators. 
A full picture of the economy needs to incorporate the constraints on fiscal policy set by the government budget in equilibrium. As a starting point, consider the periodical budget of the government. Assume that in each period, the government spends an amount $G_{t}$ and pays interest on the amount of debt at the beginning of the period, $B_{t}$. To finance these items, the government might take net tax payments of the young generation, $M_{t}^{1}$, and of the old generation, $M_{t}^{2}$, or issue new bonds. Therefore, the periodical government budget constraint is given by

$$
M_{t}^{1}+M_{t}^{2}+\left(B_{t+1}-B_{t}\right)=G_{t}+r_{t} B_{t}
$$

The fiscal balance rule is obtained in the steady-state of the model, in which - by construction - the intertemporal budget constraint resembles the periodical budget constraint. In a steady state, all budget items are constant in per capita terms. Normalizing (4) to the size of the young generation and considering the rate of population growth, yields the steady-state budget condition

$$
m^{1}+\frac{m^{2}}{1+n}=g+(r-n) b,
$$

where $b$ represents government debt per capita of the young generation, and $m^{1}$ and $m^{2}$ denote the net tax payment per capita of the young and the old generation, respectively. This condition states the well-known result that when the interest rate exceeds the rate of population growth, i.e., in a dynamically efficient economy, issuing debt eventually leads to higher per capita taxes, since the population grows at a slower pace than interest payments.

But, as for the individual decision, not only the size of the public sector matters but also the way it redistributes across between the young and the old. This is better seen by rearranging (5) to obtain

$$
m=g+\frac{r-n}{1+n}\left[(1+n) b-\frac{m^{2}}{1+r}\right]
$$

where $m$ represents the present value of lifetime net tax payments made in steady-state, as before: $m=m^{1}+\frac{m^{2}}{1+r}$. Equation (6) states the steady-state financing constraint of the government in terms of generations' life-cycle tax burden. Leaving aside macroeconomic feedbacks, one might reinterpret this relation as a fiscal balance rule, where the relevant fiscal policy parameters are the lifetime tax burden, the net tax burden imposed 
on the elderly, government consumption per worker and debt per worker. Whenever the government changes one of these parameters and does not counterbalance the impact of this change on the steady-state budget by adjusting at least one of the other parameters, generational redistribution occurs.

This concept of fiscal balance is by far more informative than the conventional notion of periodical budget balance. On the one hand, looking at the steady-state condition (6) reveals the perhaps somewhat surprising result that a deficit policy does not necessarily contradict the notion of intergenerational fiscal balance. Suppose a situation where there is no debt initially. Now, the government decides to issue bonds, so that $b>0$. However, if at the same time it imposes a positive net tax for the elderly satisfying $m^{2}=(1+r)(1+n) b$, the deficit policy does not change agents' lifetime net taxes in steady-state $m=g$, and is therefore consistent with generational balance. The reason is that for $m$ to remain constant, since $m^{2}>0$ by assumption, the tax burden on the young needs to be reduced to achieve a steady-state. In other words, intergenerational redistribution through the tax system (from old to young generations) neutralizes intergenerational redistribution through debt (from young to old generations). ${ }^{4}$

On the other hand, the steady-state condition illustrates that no deficit policies can lead to intergenerational redistribution. Consider the policy of introducing a PAYG pension system, which means that transfer payments to the elderly, in each period, are equal to contributions paid by the young generation: $-m^{2}=(1+n) m^{1}$. As the budget is always balanced, this scheme does not accumulate any debt. Nevertheless the policy requires to raise tax levels in steady-state, leading to intergenerational redistribution. Abstracting from government consumption, it follows from (6) that $m=\frac{(r-n) m^{2}}{(1+r)(1+n)}>0$.

So far, we have analyzed only a partial equilibrium abstracting from repercussions of fiscal policy on factor prices. The general equilibrium equivalent of the fiscal balance rule is easy to derive by integrating the capital market clearing condition, implying that funds provided by private savings equal demand by investors and the public sector. In our two period OLG-model, the steady-state on the capital market is described by

$$
s^{1}=(1+n)(k+b)
$$

\footnotetext{
${ }^{4}$ As noted above, debt does not necessarily redistribute in this model. The standard result of redistribution from young to old if $\mathrm{r}_{\not n}$, is achieved, for example, by assuming that the government introduces bonds $b>0$ and government spending is finances by taxes from the young $m^{1}=m=g$.
} 
where $k$ denotes capital per capita of the young generation, which means that the young generation takes over the capital stock and government bonds held by the old generation, and finances the additional demand for funds associated with population growth. Substitution of (7) into the period budget constraint of the elderly yields the steady-state level of lifetime net taxation in general equilibrium, as follows

$$
m=g+\frac{r-n}{1+r}\left[\frac{c^{2}(w, r, m)}{1+n}-(1+r) k\right] .
$$

Kotlikoff (1993) refers to this condition as the fiscal balance rule. Similar to our interpretation of the partial equilibrium condition (6), it provides first of all a description of the steady-state lifetime tax burden. If consumption of the retired generation is larger than the return from their own capital acquired when young which, in a setting abstracting from private intergenerational transfers, is only possible if the government re-allocates resources to the elderly, the steady-state tax burden $m$ is larger than what is required to finance government consumption. ${ }^{5}$ Thus the fiscal balance condition highlights that redistribution to the benefit of the elderly eventually imposes a burden on the economy, as far as the interest rate exceeds population growth rate (dynamic efficiency condition).

A normative interpretation of the fiscal balance rule, calling for generational neutrality of fiscal policy, would be - '... extract enough from each successive generation such that if you were in the stationary state you would stay there and not impose a larger or smaller burden .. on subsequent generations.' (Kotlikoff 1993: 34). This instruction highlights the consequences of a change in fiscal parameters implemented by the government. It will lead the economy into a new steady-state, which is characterized by a lifetime tax burden which is different from the current one, unless the government also adjusts other fiscal policy parameters counterbalancing the redistributive effect of the first measure. Of course, one might question this normative benchmark, given that intergenerational redistribution might be exactly the intention of the policy initiative. In this case, the fiscal balance rule still would be useful for an informed statement on the direction and size of the potential redistributive effects.

However, the fiscal balance rule seems ambiguous for an economy out of equilibrium. By simulating different policies to implement the fiscal balance rule in disequilibrium, Kotlikoff (1993) shows that this benchmark neither determines a unique lifetime tax burden,

\footnotetext{
${ }^{5}$ Without redistributive intervention, it must be true that $(1+r) k=c^{2} /(1+n)$ as agents can only rely
} on their own resources, and hence the bracketed term in (8) vanishes. 
nor a unique transition to intergenerationally balanced fiscal policies. As a consequence, the long-term equilibrium and generational welfare effects achieved by adhering to the fiscal balance rule are indefinite.

Nevertheless, the fiscal balance rule provides a theoretical reasoning to substantiate the claim of equal lifetime net tax burdens for different generations providing the benchmark for GA. The technique is an empirical exercise testing if the prospective development of government spending and revenue corresponding to current decisions about fiscal policy parameters is sustainable in the sense that it is consistent with an intertemporally balanced government budget. Fiscal sustainability therefore is a precondition of equal lifetime tax burdens by generation. Furthermore, if the test reveals that the given fiscal policy parameters are not consistent with fiscal balance, GA provides indicators for the extent of fiscal adjustment required to lead government finances back onto some consistent long-term path.

\section{Evaluating Generational Accounts}

In this section, we describe how GA evaluates the present value of lifetime net tax burden of a generation, in this context referred to as a generational account. Usually generational accounts are strictly forward-looking. This implies that generational accounts for living generations cannot be compared in a straightforward manner, since their value reflects a different remaining lifetime. This important limitation is owed to the enormous amount of data required to recover previous tax payments and transfer received, reaching back several decades into the past. ${ }^{6}$

To simplify the exposition, we describe calculation of generational accounts only for the representative member of an age cohorts. The extensions necessary to handle heterogeneity within generations are straightforward. Decompositions of generational accounts found in the literature are analysis of the net tax payments of males vs. females (Jensen and Raffelhüschen 1997), natives vs. migrants (Bonin et al. 2000), and the employed vs. the unemployed (Abío et al. 2003).

Consider a given base year $t$. GA calculates the present value of net tax payments

${ }^{6}$ Attempts at backward-looking generational accounts, which involve some heroic assumptions, were made by Auerbach et al. (1995) for the U.S. and Ablett and Tseggai-Bocureziou (2000) for Australia. 
upon death by a member of a living generation, $G A_{k}$, as

$$
G A_{k}=\sum_{i=t}^{k+D} \tau_{i, i-k} S_{i, i-k}(1+r)^{t-i},
$$

for $k \leq t$, where $S_{i, j}$ is the probability in period $i$ that an agent of age $j$ survives until the following period. The amount of net taxes paid in period $i$ by an agent of age $j$ is denoted by $\tau_{i, j}$. Finally, $D$ stands for the maximum possible lifespan, and $r$ is the discount rate reevaluating future payments to their base year worth. As the method ignores possible general equilibrium feedbacks, the assumed discount rate is a constant. A similar expression is applicable to the generational accounts of future generations, born in $k>t$, which we denote by $G A_{k}^{f}$ :

$$
G A_{k}^{f}=\sum_{i=k}^{k+D} \tau_{i, i-k} S_{i, i-k}(1+r)^{t-i} .
$$

The parameters $S_{i, j}$ entering into calculation of the generational accounts are age-specific (and perhaps cohort-specific) survival probabilities, and can be evaluated on the basis of death orders contained in standard life tables provided by demographers. ${ }^{7}$ The prediction of future mortality rates requires analysts to make discretionary choices about the evolution of life expectancy, which might complicate comparisons of GA results. From a methodological point of view, good practice is to start from a benchmark using constant life expectancy. Most GA studies do not follow this rule, however, probably because gains in longevity are generally considered a relevant source of fiscal imbalance.

It seems worth mentioning that early GA studies did not derive cohort survival rates at the micro level, but inferred them indirectly by looking at the development of aggregate cohort sizes taken from population forecasts. This approach, however, might yield biased generational accounts. If the future size of a generation is affected by migration flows, migrants' net tax payments are implicitly added to the generational accounts of natives. Under regular circumstances, this implies that the net tax payments obtained for younger age cohorts are too large (Ablett 1997).

The projection of future age- and cohort specific net tax payments $\tau_{i, j}$ entering into the generational accounts is conceptually more difficult. Two questions need to be

\footnotetext{
${ }^{7}$ Any updates accounting for likely future changes in life expectancy can be obtained recurring to standard models of demography. Bonin (2001) contains a detailed description of a population model, as required for any GA study.
} 
addressed. Firstly, what is a meaningful concept of net taxes that should built into the generational accounts? Secondly, what is a meaningful concept for making fiscal projections at the individual level that need to cover a very long time span? We begin with an answer to the first question.

In general, GA is used to analyze the sustainability of fiscal policy at the level of the entire public sector. ${ }^{8}$ For this purpose, it is necessary to incorporate all taxes paid to and transfers received from all federal levels of government, including off-budget authorities like publicly administered social insurance schemes. Still, different GA studies use different concepts of net taxes. Ambiguities mostly arise from the interpretation of the substantial part of government spending which is not given as a direct transfer to private agents. This item includes, for example, government spending on goods and services, but also investment and subsidies to private companies.

In the GA literature, there are two competing approaches to handle non-transfer spending in the government budget. The first approach, following the principles of the pioneer study by Auerbach et al. (1991) puts a stronger emphasis on who pays for government spending than on who benefits from it. Consequently non-transfer expenditure is basically excluded from the generational accounts. Exceptions are usually made for public spending on institutions like education and nursery care, which are assigned as a transfer to beneficiaries at input costs. ${ }^{9}$ This procedure might justified with an opportunity cost argument - agents would be worse off without public provision of these institutions, for they would need to put more of their own funds into them otherwise.

The previous approach has been criticized by Haveman (1994) and Buiter (1997), among others, for ignoring that non-transfer spending of the government might create public goods enhancing private welfare. For example, reduced investment in public infrastructure would not change the generational account, if a transfer concept excluding in-kind receipts is applied. In fact, it seems that the conservative definition of the net tax burdens tends to encourage the false notion that agents with a positive lifetime tax burden would be better off without a government.

In order to acknowledge that government spending might translate into private ben-

\footnotetext{
${ }^{8}$ In principle, it is possible to apply GA to smaller government bodies. However, evaluation of generational accounts is much more difficult in this context, since one has to handle inter-governmental flows of funds or individuals. So far, Baker et al. (2002) is the only example of GA at the Federal State level.

${ }^{9}$ Franco et al. (1992) are the pioneers of this approach.
} 
efits, Raffelhüschen (1999) and ter Rele (1997) propose to include all non-transfer expenditure in the generational accounts, which they attribute as a lump sum to each individual. This procedure leads to a reinterpretation of the generational accounts, which become a welfare indicator, instead of a measure of how fiscal policy interferes with lifetime consumption opportunities of individuals by extracting net taxes. This alternative interpretation also is not unproblematic. Consistent application of the welfare principle would require knowledge of how public spending impacts on individual well-being. Measuring possible benefits by the input value of public goods might by misleading. Obviously, the cost value of government purchases might not be equal to the social value, considering externalities. Moreover, when government expenditure is included in the generational accounts, efficiency gains, i.e. provision of the same level of services at lower costs, would show up as a higher lifetime net tax burden; see McCarthy and Bonin (1999) for an example of this misleading result in the GA context.

At any rate, the lump-sum principle for assigning public expenditure not targeted to clearly identified age groups, seems questionable at least for public investment. Assuming the investment is profitable, it would be necessary to allocate the stream of returns across cohorts when it occurs rather than when the investment is made. Arguing that younger generations have a higher chance to profit from the investment given their longer lifespan, one might claim that a downward-sloping age-benefit profile is more appropriate, although construction of an empirically meaningful benefit profile is cumbersome. ${ }^{10}$ If only a constant age-profile (at input costs) is employed, generational accounts as welfare indicators might exaggerate redistribution across generations, as they concentrate the entire potential benefits of public investment on the year when it is made.

In an attempt to reconcile the two approaches, Bonin (2001) suggests to evaluate generational accounts on the basis of the conventional definition of net taxes excluding government purchases, and to calculate the lifetime present value of government purchases separately, using the construction principle of generational accounts given by (9). This approach has the advantage that it avoids the somewhat problematic interpretation of government purchases impacting directly on individuals. Instead, any gap between generational accounts and generational government purchases, called a cohort deficit (re-

${ }^{10}$ Cardarelli and Sefton (1999) introduce age-profiles for public investment into GA, but these are cost based profiles. 
spectively a surplus), is regarded as a financial imbalance impacting on the intertemporal budget of the government. If a positive cohort deficit is obtained, this implies that remaining lifetime net taxes retrieved from a generation do not recoup government purchases made over the lifetime of this generation. As a consequence, the generation is associated with a deficit in the intertemporal government budget that needs to be covered by a cohort surplus drawn from some other generation, is fiscal policy were to be sustainable.

Note that, whatever the concept of net taxes used for GA, the aggregate of net taxes is not necessarily identical to public revenue net of public expenditure. A first reason is that transfers received from abroad do enter the government budget, but not the generational accounts. This is important for GA in developing countries, see Kakwani and Krongaew (1999) and Altamiranda (1999), but might also be a relevant issue for European countries benefitting from financial support by the EU. More importantly, transactions between the government and economic agents that generate an exchange in return are excluded from the calculations. For an example, consider interest paid on debt, which constitutes a return on private lending, and not a transfer. Likewise, user fees are not a part of the private tax burden.

We now turn to the second question of how to project future net tax payments by year and age, $\tau_{i, j}$. The first step is to divide net taxes into individual taxes paid and transfer received. The procedures described in the following are separately applied to each identified tax and transfer category. For simplicity, however, we maintain the notation $\tau$, which now refers to a specific tax $(\tau>0)$ or transfer $(\tau<0)$. The starting point of the projection is a tautology - initially the tax or transfer amount observed in the government budget $T_{t}$ must be equal to the sum of individual payments by cohort, weighted by cohort size. Therefore, one can write

$$
T_{t}=\sum_{j=0}^{D} \tau_{t, j} P_{t, j},
$$

where $P_{t, j}$ denotes the size of the generation of age $j$ in period $t$. However, available micro data on tax and transfer receipts by age will never measure $\tau_{t, j}$ such that the identity (11) is satisfied. Generational accountants therefore proceed in two steps: in a first step, they derive the best possible relative age profile at the micro level, $\left(\tau_{0}^{*}, \ldots, \tau_{D}^{*}\right)$, where the index refers to age. The age vector obtained from micro data does not necessarily relate to the base period and therefore does not have a time index. Typical resources exploited 
at this stage are register data, national surveys on income and consumption behavior, and longitudinal surveys of private households.

So far, generational accountants have not attempted to systematically separate between age and cohorts effects even when they use panel data for retrieval of relative payment positions of different age groups; see Fullerton and Rogers (1993) for an econometric method of estimating life-cycle tax profiles on panel data. This might be a major neglect - results obtained by Banks, Disney, and Smith (2000) indicate that lifetime fiscal payments profiles might indeed vary considerably across cohorts. For an integration of cohort effects into the GA procedure, it would be necessary to gather information on a set of age profiles, $\left(\tau_{0 k}^{*}, \ldots, \tau_{D k}^{*}\right)$, distinct by cohort $k$. Identification of cohort effects, however, often proves to be empirically difficult, because longitudinal fiscal data at the micro level are not available in sufficient detail.

In a second step, it is assumed that the true age profile of payments in period $t$ is proportional to the observed profile. Assuming that there are no cohort effects, this leads to $\tau_{t, j}=\varepsilon \tau_{j}^{*}$. The constant adjustment factor $\varepsilon$ is determined by solving

$$
\varepsilon=\frac{T_{t}}{\sum_{k=0}^{D} \tau_{j}^{*} P_{t, j}},
$$

in order to guarantee that the tax or transfer micro profile at the starting point of the GA projections fits the corresponding budget aggregate in the base year.

As a general rule, the re-evaluated profile obtained for the base period is kept constant for the evaluation of generational accounts, except for the impact of economic growth. The accounts reflect economic growth in real terms, which implies that their value is expressed in terms of base year prices. ${ }^{11}$ Growth effects are usually designed in a most simplistic manner - it is assumed that productivity growth increases future individual age-specific tax and transfer payments, as well as per capita government spending, at a uniform and time-invariant annual rate $g$. Therefore, any future payment can be expressed in terms of the payment profile at time $t$, as follows

$$
\tau_{t+i, j}=(1+g)^{i-t} \tau_{t, j},
$$

for $j=1, \ldots, D$. Given that wages on competitive labor markets grow at the rate of

${ }^{11}$ Nevertheless inflation might be incorporated in the net tax burden, if seignorage is interpreted as a tax on money holding. 
productivity growth at least in the long term, this procedure implies that net income tax rates evaluated over the entire life-cycle do not depend on the assumed growth rate.

In principle, the same goal can be reached by a different growth rule postulating that per capita lifetime payments grow at a constant rate over the sequence of birth cohorts. This approach might require cohort-specific growth factors which are a function of life expectancy. It is easy to show that this alternative contains (13) as a special case. In some applications, the lifetime growth rule might indeed better represent the current stance of fiscal policy. Consider, for example, a policy where the pension level at entry into retirement is determined on the basis of previous earnings, whereas the pension payments are indexed to inflation. As a consequence, only the aggregate of pensions received over the entire life-cycle would probably grow at the rate $g$, but not the annual pension payment. It is therefore not surprising that the generational accounts obtained by this method are generally smaller; see Levy and Doré (1999) and Cardarelli and Sefton (1999) for examples. A major difficulty of implementing the life-cycle approach is that it requires empirical results on payment profiles distinguishing by age and cohort, as discussed above.

Constant growth uprating according to the annual growth rule given by (13) has the effect that budget aggregates grow at the rate $g$ unless there are changes of fiscal policy or demographics. As a consequence, the GA measures tend to perpetuate the initial business cycle conditions. This aspect is important for a correct interpretation of generational accounts. In general, government tax revenue increases and transfer spending falls during a boom, whereas the opposite happens during a recession. Accordingly life-time net tax burdens measured by the generational accounts develop pro-cyclically. ${ }^{12}$ As a consequence, fiscal policy might appear more or less sustainable, depending just on the macroeconomic stance in the base period of the projection.

There are different solutions to avoid business-cycle bias in the generational accounts. A first approach would be to take a period with average utilization of economic capacity as the starting point for the calculations. This idea has not been realized by generational accountants, who are generally aiming at evaluation of contemporaneous fiscal policy, which might be different from that in the period that was neutral with respect to the economic cycle. Another method, employed by analysts, is to use the contemporaneous

12 This variation is evident, for example, in a sequence of GA studies capturing the Norwegian economy at different stages of the business cycle; compare Auerbach et al. (1993) and Steigum and Gjersem (1999). 
government budget as a starting point, but to make discrete adjustments during the forecast that design a return to what is considered a cyclically neutral state. ${ }^{13}$ The typically ad hoc nature of the required assumptions on the transition is a serious point of criticism against this approach. A more systematic procedure, recently applied to Spain by Patxot and Bonin (2004), is to base the evaluation of generational accounts on cyclically-adjusted government budget aggregates as evaluated, for example, by the European Commission, instead of the actual budget figures.

Even if the forecast of future fiscal payment streams at the individual level starts from a cyclically neutral budget, the mechanical growth rule of GA requires explanation. A justification offered by generational accountants is that over very long time spans, per capita tax payments or transfer receipts cannot grow at a different rate than the economy (Congressional Budget Office 1995). If they did, the forecast value of the budget item, as a share of domestic product, would eventually grow to zero or infinity, for annual growth rates smaller or larger than the growth rate in the economy, respectively. In other words, taxes (transfers) are not progressive (regressive) - those taxes or transfers not automatically indexed to economic growth will be adjusted at some point in time such that they can catch up with the development of the economy. Under some circumstances, this perspective might not reflect the actual intentions of fiscal policy. Delayed indexation, especially indexation of payments to the inflation rate, might be used explicitly as a means of reducing replacement rates of transfers, or to raise (income) tax revenue. ${ }^{14}$ In such cases, it might be necessary to temporarily deviate from the constant growth uprating rule for an accurate representation of current fiscal policy. Nevertheless the projection procedure eventually must return to the constant growth rule.

Mechanical application of a uniform growth rate furthermore implies that economic growth does not change the age profile of fiscal payments, meaning that the expansion of the economy does not favor specific age groups at the expense of others. However, there are many reasons to expect cohort-specific gains (or losses). If the benefits of economic growth are related to agents capability to innovation, net taxes of younger generations might grow comparatively faster due to earnings growth. Economic growth might also

13 A GA study for Finland by Feist et al. (1999) contains an example of this procedure.

${ }^{14}$ For example, in the UK price indexation is used as a long-term strategy to cut the level of minimum pensions; see Cardarelli and Sefton (1999). 
affect the probability that a payment occurs differently across generations. For example, changes in labor market conditions might lead to variation in unemployment rates, and labor market participation rates, that probably are not uniform by age (Abío et al. 2003).

Considering these arguments, it is evident that the GA procedure does not aim at accurate measurement of generations' net tax burdens. For older birth cohorts, predictive quality of the generational accounts is likely to be poor. A larger share of their payments is counted over a relatively short time horizon when payments might deviate substantially from any long-term trend. For younger birth cohorts, generational accounts tend to be biased due to ignorance of cohort effects. What is a loss in predictive quality, appears however as a gain in indicator quality. The mechanics of the forecasting procedure is transparent: at the micro level, the initially observed relative distance between net tax payments across age groups, but also between specific taxes and transfer payments, stays constant. Thus GA manages to condense complex information about the status quo current fiscal policy in combination with demographic parameters to a compact measure.

This principle to summarize information on lifetime events reflected in a current cross-section is well-established in demographics. For example, consider the life expectancy at birth measure. It is not a viable prediction of current newborns' average lifespan, but represents the average lifespan conditional on the stylized but reproducible event that the current vector of cross-sectional survival rates does not change in the future. In a similar fashion, generational accounts indicate counterfactual lifetime tax burdens conditional on perpetuation of current fiscal policy parameters. Interpreting net tax burdens measured by GA, it is important to acknowledge this indicator quality of the generational accounts.

Although GA is generally based on the principle of constant fiscal policy parameters, most empirical applications found in the literature deviate from this standard in two ways. Firstly, often discretionary adjustments are introduced such that the forecast captures situations where legal amendments enacted in or prior to the base period are expected to unfold their budget impact only in future periods. This practice sometimes is even extended to integrate official short- and medium-term budget forecasts. ${ }^{15}$ The latter appears questionable practice. Inclusion of what is often embellished intentions rather than policy commitment is at least somewhat at odds with the idea of a well-defined

${ }^{15}$ For examples see GA studies prepared by the Office of Management and Budget (1994) and Bovenberg and ter Rele (1999). 
indicator concept. Secondly, more complex forecasting schemes might be applied to assess the impact of counterfactual fiscal policies on the generational accounts. Obviously, such policy experiments first require neutral status quo indicators for a persuasive benchmark.

Adjustments to the basic forecasting procedure described by (13) might take two different forms. On the one hand, fiscal policy might leave the relative age profile $\left(\tau_{0}^{*}, \ldots, \tau_{D}^{*}\right)$ unchanged while shifting the aggregate value of the corresponding budget item. In technical terms, the budget impact of this policy is captured by an adjustment of the constant of proportionality $\varepsilon$. This might be a satisfying design, for example, when analyzing changes in (proportional) payroll contributions schemes. On the other hand, policy decisions might be targeted at specific demographic groups, thereby altering the relative position of age cohorts in the payment vector. A change in the legal retirement age is an example for such an effect. In such a case, one would re-design $\left(\tau_{t, 0}, \ldots, \tau_{t, D}\right)$ given $\varepsilon$ such that the vector represents the assumed structural age effect, and follow (13) to make updates for the future.

In order to avoid a fundamental misunderstanding, it seems useful to highlight at the conclusion of this section, that GA might even be contradictory to existing government institutions. Any pay-as-you go scheme in the public sector by definition continuously balances aggregate expenditure and revenue. At least in principle, this type of financing scheme requires to accommodate replacement or contribution rates as soon as a deficit or surplus occurs, to always guarantee a balanced budget. More generally, one might claim that fiscal policy is responsive if maintenance of the initial payment levels accumulates unwanted deficits or surpluses in the future. In other words, the payment profiles at the individual level fundamental to the generational accounts are likely to be responsive to the development of government budget. Still the forecasting procedures discussed in this section do not reproduce any endogeneity of payment profiles that emanates from the macro level, as Diamond (1996) remarks in a famous critique of GA.

These observations, however, only confirm once more the indicator quality of the generational accounts, which must not be confused with predictions. The method deliberately avoids a decision, by any means arbitrary, about when and how decision makers would make any necessary adjustment of fiscal policy. Instead, GA is satisfied with an indicator for the overally long-term imbalance in fiscal policy. This brings us to the notion of the intertemporal government budget applied by generational accountants, which is the topic of the following section. 


\section{The Intertemporal Government Budget}

In a dynamically efficient economy where the interest rate is higher than the population growth rate (adjusted for technological progress) interest payments cannot be financed by deficits in the long term. Otherwise government debt per capita of the population must explode. Respecting this condition, the sum of the annual government balances, described previously by (4), over all periods $i \geq t$, can be expressed as

$$
\sum_{i=t}^{\infty} N_{i}=\sum_{i=t}^{\infty} G_{i}+B_{t},
$$

which is the intertemporal budget constraint fundamental to the fiscal sustainability concept of the GA procedure. In (14) $N_{i}$ stands for the aggregate net tax revenue of the government in period $i$, and $G_{i}$ is the value of government purchases made in period $i$. Both items are expressed in terms of their present value at period $t$. This re-evaluation guarantees that the infinite sums converge to finite values. In a dynamically efficient economy, the addends do not grow as much as the discount factor. Finally, $B_{t}$ denotes the value of the government debt, net of government assets, inherited at the base period $t$.

For an interpretation of $B_{t}$ consider for convenience that future interest and growth rates are known with certainty and that all debt is short-term. The government actually might use a wide range of debt service arrangements, but we only look at the two extreme cases. The first is that the government in every period pays the interest falling due. This means that the principal needs to be refinanced in every period. As the value of the debt stays constant, its present value declines - pushing the time horizon far enough away, the latter becomes arbitrarily close to zero. This is the standard situation of the finance literature. The value of the (negative) asset is equal to the discounted value of all future debt servicing. It follows as a corollary that if debt were to be traded on the market, it would exactly cost the face value $B_{t}$. This result actually holds more generally, for any situation with debt growing at a slower rate than the interest rate, over an infinite time horizon.

The second extreme case is that the government never repays its debt and finances interest payments by issuing new bonds. This means that the growth rate of government debt that needs to be refinanced every period is equal to the interest rate. Considering that the present value of future debt obviously does not converge to zero, intuitively it 
would seem that the market value of government debt deviates from its face value in this case. However, it can be shown that under the condition that the interest rate exceeds the growth rate of the economy, i.e. in a dynamically efficient economy, the market value of government debt again exactly matches its face value, see Cohen (1985) for a statement of the easy arithmetic proof. The intuition for this result is that although the debtor never makes a repayment, government debt stays constant in present value terms, as public liabilities grow at exactly the discount rate.

Only in the case that the economy grows faster than the interest rate, the market and face values of government debt differ. Debt is worth more than the present value of repayments (zero, in our example), since savers holding it can expect to sell it, swelled by the interest rate, to future savers. In this - empirically not supported - case of a dynamically inefficient economy, the question of fiscal sustainability is irrelevant altogether. Debt always declines relative to GDP. Since time devaluates government liabilities, it is possible for the government to run primary deficits in order to reduce the current net tax burden without the necessity to raise the net tax burden of some future generation by more than an arbitrarily small amount, by pushing repayment far enough into the future.

These examples clarify that if the government, in a dynamically efficient economy, does not indefinitely finance interest payments by issuing bonds, it can satisfy the socalled no-Ponzi game condition that debt asymptotically must not grow at a faster rate than interest payments. If it did, it would be likely to enter into the vicious circle of ever increasing per capita debt, implying a rise in lifetime net tax burdens; see Blanchard and Fischer (1989) for a formal statement. A possible critique of the no-Ponzi game condition rests on the argument that public debt is a means of risk pooling in incomplete financial markets, which do not offer the small-risk equities private agents demand (Blanchard and Weil 2001). Given that there are economic gains from the risk pooling property of public debt, it might in fact be possible to run deficit policies without the necessity to tighten future government budgets.

However, even if there is some empirical evidence in support of the hypothesis that some of the interest rate differential between equities and bonds is attributable to riskpooling on incomplete financial markets (Mehra and Prescott 1985), it seems hardly sufficient to base long-term fiscal policy decisions exclusively on this hypothesis. ${ }^{16}$ That is,

16 The Congressional Budget Office (1995) discusses this issue comprehensively. 
prudent fiscal policy is a kind of intergenerational insurance. Ball et al. (1995) argue that it helps to avoid that some agents are left with an excessive bill, if at some point in the future, it turns out that continuous debt rollover is impossible. Following this perspective, the intertemporal financing constraint given by (14) imposes a risk premium on not so distant generations who are asked to share the potential burden from public debt by financing part of the interest.

A more straightforward interpretation of the intertemporal government budget constraint is that it represents the sum of future annual primary deficits or surpluses, $N_{i}-G_{i}$, in present value terms. From this perspective, (14) illustrates that sustainable fiscal policy, i.e. fiscal policy satisfying the no-Ponzi condition, is consistent with existence of primary deficits (or surpluses) in the long term. This is obvious, given that the financing constraint faced by the government does not require to balance yearly primary budgets. However, if long-term primary imbalances exist, interest payments (returns) resulting from the accumulated debt (assets) must be counterbalanced at some other point in time via a combination of net tax payment and government expenditure parameters leading to primary surpluses (deficits). For example, the intertemporal budget constraint allows that persistent primary deficits following a demographic transition to higher old-age dependency are pre-funded by saving part of the tax payments made by the relatively younger population prior to the transition.

The purpose of GA is to combine this intertemporal perspective on the limits of government debt with the generational perspective on net tax burdens imposed by fiscal policy, as discussed in the previous section. Switching to a generational perspective, the intertemporal government budget constraint can be re-written as

$$
\sum_{k=t-D}^{\infty} N_{k}=\sum_{i=t}^{\infty} G_{i}+B_{t}
$$

where $N_{k}$ stands for the aggregate net payments to the government budget made by the generation born in $k$, in periods $t \geq t$, i.e. from the base period to death, expressed as the present value of period $t$. Equivalently, by inserting the generational accounts defined by (9) and (10), we may write

$$
\sum_{k=t-D}^{t} P_{t, t-k} G A_{k}+\sum_{k=t+1}^{\infty} P_{k, 0} G A_{k}^{f}=\sum_{i=t}^{\infty} G_{i}+B_{t} .
$$

Fiscal sustainability demands that the generational accounts of presently living and future 
born generations, weighted by the respective size of the different generations balance the present value of government expenditure and interest payments. The formulation of the intertemporal financing constraint to fiscal policy given by (16) is the starting point for the indicators of fiscal sustainability indicators derived by generational accountants. ${ }^{17}$ However, before moving to a discussion of these indicators, we first take a closer look at how to evaluate the RHS variables of the equality.

Regarding the content of the variable $G_{i}$, it is obvious that the budget items summarized under this heading depend on the concept of net taxes applied to construct the generational accounts, recall the discussion in Section 3. As a rule, the variable encompasses all government spending that is not associated with transactions involving a direct exchange between the private and the public sector, like fees and interest payments, and all spending net of revenue not registered as a net tax by the generational accounts. This implies that in GA applications which treat any government activity as an implicit transfer, the RHS of (16) might be reduced to $B_{t}$.

To avoid confusion about the content of what is basically only a residual variable, a useful label for $G_{i}$ might be net government purchases, as opposed to the private net tax payments appearing on the LHS. In the GA literature, the variable is also addressed simply as government consumption, or as non-age-specific government expenditure. The former is probably misleading, since the GA concept of net government purchases is very different from government consumption contained in National Accounts data. The latter ignores that in several applications, net government purchases are not treated as constant by age, see the study by Feist et al. (1999) for an example of $G_{i}$ including age-dependent subsidy payments.

The general approach of generational accountants to forecast future net government purchases closely resembles that applied for projection of future net tax payments - a profile of net government purchases by age evaluated at the micro level, perhaps entirely flat depending on the data availability, is subjected to the uniform rate of economic growth, $g$. Prospective budget aggregates are then retrieved by combining the individual level forecast with future population vectors.

In contrast, determination of the proper value of government debt net of government

${ }^{17}$ For simplicity, (16) ignores the adjustments necessary to account for immigrants' fiscal contributions, which are explained by Bonin et al. (2000). 
assets, $B_{t}$, raises difficult conceptual and valuation issues. In an ideal world, arbitrage on perfect capital markets guarantees that government bonds bear the average market rate of interest. If their return is higher (lower) than average, the market value of bonds depreciates (appreciates), restoring the equality. If one furthermore assumes that the appropriate rate for discounting future payments is equal to the market rate on bonds, it follows that the current face value of approximates the discounted stream of future interest payments. However, the theoretical and empirical issue of the appropriate discount rate attached to future payments that are uncertain because of the possibility of fiscal policy changes is not ultimately settled. With some probability, it is not given by a current market rate of interest on government bonds. ${ }^{18}$

Therefore, in practice correct evaluation of the market value of government bonds, often reported in nominal terms, and government tangible assets, often not tradable by nature and typically entering into the books at replacement cost, is difficult. Generational accountants frequently seem to withdraw from the task when they only account for the nominal value of government bonds, and for government assets that bear a positive reported return. The latter are often treated as an item reducing net government purchases. But this is probably misleading, considering that the evolution of net government purchases, as explained above, is tied to the evolution of economic and population growth. At least, there seems to be no obvious argument why government revenue from tangible assets would strictly follow the economic and especially the demographic development, unless one claims that these returns resemble a user charge on citizens received for utilization of public infrastructure.

A more convincing procedure, originally implemented by Auerbach, Gokhale, and Kotlikoff (1991), is to capitalize the observed return on government assets in the base year, excluding revenue from asset sales which represents a non-recurring gain, by application of a constant rate of nominal interest. As the observed payment represents a nominal return, the result needs to be corrected for some long-term value of inflation, to be consistent with the generational accounts, which are measured in real terms.

For a more accurate representation of future interest payments on government debt, or the future return from government assets, some analysts evaluate the prospective value

18 Haveman (1994), Auerbach, Gokhale, and Kotlikoff (1994), Diamond (1996) and Auerbach and Kotlikoff (1999) discuss the discount rate problem in the GA context. 
interest payments considering a sequence of future interest rates deviating from the discount factor applied elsewhere in the GA procedure. Bovenberg and ter Rele (1999), for example, account for the fact that government ownership of housing bears a systematically lower return than financial assets. A related example refers to the evaluation of the value of depletable government resources, which by definition cannot lead to an infinite stream of revenue, and therefore require explicit specification of the corresponding sequence of returns (Steigum and Gjersem 1999). This is a relevant topic in many counties with public ownership of minerals, but the procedure might be equally relevant in the context of government receipts from privatization. A final example is an explicit design of gradual transition to long-term average interest rates underlying the GA procedure, which might be possible given sufficiently detailed information on the current interest rate and term structure of government debt. Empirical results obtained by ter Rele (1997) indicate that application of a constant long-term interest rate might indeed misrepresent the financing needs of the government indicated by the intertemporal budget constraint.

In view of these complexities, it seems likely that the measure of government debt required for an empirical evaluation of the intertemporal government budget constraint given by (16), misrepresents the true value of the government liabilities that at the base year are a datum for fiscal policy. GA in fact has been criticized for replacing an ill-defined concept of government deficits with an ill-defined concept of government debt or wealth (Ablett 1996). However, understanding the method as a tool to generate meaningful fiscal sustainability indicators, and not to generate accurate predictions of the long-term development of government budgets, this point seems not well taken. The status quo approach of GA to approximate the value of future interest payments has its complement in the simplistic growth rules employed to project future net tax payments. In either case, application of more elaborate forecasting strategies, likely to require more discretion from analysts, might comprise on the indicator quality of the GA procedure. The spread of possible outcomes in face of uncertainty about the future might be acknowledged instead by performing thorough sensitivity tests. In any case, the issue of adequate government wealth measures seems less relevant in the realm of comparison between policy alternatives for the future. The differential impact of two policies on fiscal sustainability does not depend on the initial value of debt, a reflection of past fiscal policy. 


\section{$5 \quad$ Fiscal Sustainability Indicators}

Given that the lifespan of the state is longer than that of its citizens, and that the time horizon of economic agents is finite because of imperfect inter-generational altruism, the government might use fiscal policy to redistribute across generations. ${ }^{19}$ Abstracting from any general equilibrium effects, the intertemporal financing constraint of the government given by (16) encourages the interpretation of fiscal policy as a generational zero-sum game - any policy that raises the generational account of some generation ceteris paribus forces to reduce the generational account of some other generation. In particular, it seems suggestive to draw a line of conflict between currently living and future born generations. Depending on the value of aggregate net tax payments made by the living (represented by the first sum on the LHS of the intertemporal budget), the aggregate net tax payments of future generations (represented by the second sum on the LHS) required to balance future net government purchases and interest payments might be larger or smaller.

For an example, consider a policy that exclusively reduces the generational accounts of the generations currently alive. As a consequence, unless the cut in lifetime net tax rates is accommodated by tightening net government purchases, periodical primary budget deficits increase at some point in time. The interest payments corresponding to the accumulated debt must then be carried by future generations who face an increase in their generational accounts. Of course, which generations would face the burden of balancing the intertemporal government budget remains undetermined.

In practice, fiscal policy cannot discriminate between birth cohorts as claimed in the previous example. Given that the lifespan of generations alive and born in the future have a considerable overlap, it seems unlikely that the government can levy substantially different lifetime net taxes on consecutive birth cohorts, even if fiscal policy has some instruments to discriminate by cohort. Intergenerational links between net tax levels are likely to be relevant especially concerning the net taxes during youth of living generations and those born in the not so distant future, whereas net tax levels of older living generations are generally less of a pre-commitment for fiscal policy over the long term.

\footnotetext{
${ }^{19}$ Infinitely altruistic agents have the potential to counterbalance any fiscal policy decision by leaving a bequest (Barro 1974). Although there is empirical evidence in support of the hypothesis of weak intergenerational altruism, see Laitner and Juster (1996) among others, global intergenerational altruism is rejected, see Altonji et al. (1997) and Wilhelm (1996).
} 
Nevertheless a clear distinction between the generational accounts of living and future generations baring the fact of any additional structure in the intertemporal government budget, seems convenient for analytical purposes. Making the assumption that all future born generations bear an identical lifetime tax rate, one can re-write the intertemporal financing constraint of the government to get

$$
G A_{t+1}^{f}=\frac{\sum_{i=t}^{\infty} G_{i}+B_{t}-\sum_{k=t-D}^{t} P_{t, t-k} G A_{k}}{\sum_{k=t+1}^{\infty} P_{k, 0}\left(\frac{1+g}{1+r}\right)^{k-t-1}},
$$

which leads to the residual fiscal sustainability indicator common to the early GA literature. To summarize the degree of intergenerational redistribution associated with current fiscal policy parameters, the nominator on the RHS of (17) is first evaluated by projecting generational accounts of generations alive and future net government purchases under the condition that fiscal policy stays constant in the future. The resulting gap in the intertemporal budget, which is the part of net government purchases and government liabilities not financed by living generations, is then distributed equally among all future newborns. Their cohort size $P_{k, 0}$ is weighted by a growth factor accounting for income growth, and corrected by the discount factor taking future generational accounts back to the base year. The residual indicator given by (17) directly illustrates that ceteris paribus population decline tends to raise future generations' net tax burdens.

Generational accountants who employ this approach do not claim that a differential treatment of current and future generations by fiscal policy is actually feasible, nor that the government does not have a choice to adjust net government purchases instead of raising net taxes. The limitation of the possible adjustment in response to an intertemporal financial imbalance merely highlights the indicator quality of GA. Though acknowledging that the exact policy response is undetermined, the residual approach focuses the attention on the perspective that political decision makers optimizing over myopic goals probably have incentives to adapt fiscal policies redistributing to the advantage of current generations. As the sequence of future generational accounts conditional on a given intertemporal budget cannot be specified without making additional and by construction non-verifiable assumptions, the intertemporal financial need associated with continuation of current fiscal policy is condensed into a single index figure given by the generational account of the cohort born in $t+1$, which is representative for all future generations.

In view of this strongly stylized approach, it is obvious that the generational account 
indicator given by (17) is not an estimate of an actual net tax burden, like the generational accounts for the living derived on the counterfactual scenario of constant fiscal policy. In reality, when the government in face of a gap in the intertemporal budget adjusts fiscal policy during the lifetime of current generations, the burden on future generations is likely to be smaller, assuming it is not possible to perfectly discriminate between generations. In the alternative case that the government spears also some future generations from bearing the necessary adjustment, the generational accounts of those who do eventually bear it become even larger. In the GA framework ignoring behavioral responses, however, it is basically possible to make any assumption on the distribution of fiscal burdens. Analysts make a choice of those convenient to indicate a need for fiscal policy adjustment. Of course, the arbitrariness of this approach implies that the specific value of a single sustainability measure obtained from GA is difficult to interpret.

A question that can be directly analyzed on the basis of the index $G A_{t+1}^{f}$ is if current fiscal policy is consistent with the fiscal balance rule. Would it in principle be possible for the government to maintain the life-cycle tax rates of consecutive birth cohorts without violating against its intertemporal budget constraint? Given that apart from growth and discounting effects, the value of the generational account $G A^{f}$ is by construction identical for all future generations, an answer to this question only requires comparison with the lifetime net tax burden on generations alive. The only feasible comparison group among the living is given by the base year newborn. The generational accounts of all other age groups are not comparable as these are observed only over an incomplete life span. ${ }^{20}$ In the early GA literature, the comparison between the lifetime tax rates of future and current newborn generations is usually made in relative terms:

$$
\pi=\frac{G A_{t+1}^{f}\left(\frac{1+r}{1+g}\right)}{G A_{t}} .
$$

The relative approach has the advantage that it is not necessary to calculate the present value of life time wage income. Ignoring the possibility of bequests or other transfers across generations, lifetime earnings provide a meaningful benchmark to judge lifetime net tax rates, as they determine lifetime consumption opportunities before government intervention. Considering that the lives of two successive generations overlap for all but one year, lifetime earnings are identical except for productivity growth over one year

${ }^{20}$ Differences in projected life expectancies for present and future newborns are negligible in practice. 
(corrected by the discount factor) and therefore cancel out. Still it might be useful to report lifetime tax rates associated with the generational accounts explicitly, to provide a benchmark for gauging the relative change indicated by (18). An estimate for generations' lifetime gross labor earnings which is in the spirit of GA can be derived by combining an age profile of per capita earnings, re-evaluated in order to match labor income at the state level and subjected to constant productivity growth, with age-specific mortality rates.

But even without this complement, the generational account ratio given by (18) is a clear-cut index of fiscal sustainability. Payment levels set by current fiscal policy are in line with the fiscal balance rule only if $\pi=1$. In any other case, continuation of fiscal policy leads to intergenerational redistribution, in the sense that the intertemporal budget constraint of the government does not allow imposing identical lifetime net taxes on the present and future newborn. Given $\pi>1$, fiscal policy extracts not enough resources from the current generations to be sustainable, whereas it extracts unnecessarily much resources provided that $\pi<1$. Recalling our discussion of the fiscal balance rule, it is obvious that the benchmark $\pi=1$ by no means represents a normative statement. In particular, it does not say that decision makers should adjust fiscal parameters such that the equality is achieved. The sustainability indicator only measures if any revision of fiscal policy is necessary in the future, leading to a change in the net tax burden on some generation.

It is also important to realize that generationally balanced fiscal policy does not require a zero residual in the intertemporal budget constraint defined by the nominator of (17). Obviously, a zero residual can only be consistent with fiscal balance, if also the generational account for the newborn generation of the base year equals zero. More generally, there does not exist a unique relation between the size of the intertemporal budget residual and the fiscal imbalance indicated by $\pi$, see Bonin (2001) for an illustration using numerical examples. The source of fiscal imbalance is not the fact that current generations leave a financial obligation to future generations, but that the generational account assigned to the base year born generation is not sustainable given the resources extracted from the other generations alive. In this perspective, the budget residual consistent with sustainable public finances is a function of $G A_{t}$. The larger (smaller) the value of this generational account to be maintained for fiscal balance, the smaller (larger) the financing burden that needs to be imposed on the other living generations. This observation is important to keep in mind when using GA to compare the generational impact of different 
fiscal policies. Policies that appear identical if judged by their effect on fiscal balance, might be associated with very different levels of resources redistributed between generations. The fiscal sustainability indicators provided by GA in general are not designed to cope with this type of ambiguity. ${ }^{21}$

Empirical applications have revealed some limitations of the original GA concept to measure fiscal sustainability. A minor point is that the indicator (18) has some unwanted algebraic properties. It is undefined at $G A_{t}=0$ and converges to infinity for values of $G A_{t}$ close to zero. A high numerical value of the indicator therefore might simply reflect a small denominator rather than any serious fiscal imbalance. ${ }^{22}$ More importantly, the simple split of the residual in the intertemporal budget constraint according to population size wastes information. Firstly, the matrix of the future population is reduced to the vector of future newborns. Demographic trends affecting cohort size at a later stage of the life cycle are not respected. The most relevant example in this context is ignorance of immigrants belonging to future generations (Auerbach and Oreopoulos 2000). Secondly, it remains obscure how the policy adjustment balancing the intertemporal government budget is brought about. Hence economic trends, like growing labor force participation, affecting the fiscal capacity of a representative future agent cannot be integrated in a straightforward manner. Structural restrictions on future net taxes, for example due to long-term oriented reforms, cannot be designed either. Finally it would be impossible to comment on the possible implications for demographic groups distinguished by the structure of their tax and transfer payments.

In response to these shortcomings, Auerbach (1997) proposes an alternative approach that integrates the demographic and economic structure of future generations explicitly into the sustainability indicators. The fundamental benchmark of this approach is the sustainability gap, or generation balance gap (Cardarelli, Sefton, and Kotlikoff 2000). The sustainability gap is derived by evaluating all items contained in the intertemporal budget constraint (16) under the assumption that current fiscal policy is maintained. In

${ }^{21}$ Bonin and Feist (2003) propose a policy indicator that aims at neutralizing the differences in aggregate redistribution associated with different policies by benchmarking generational accounts against measures of cohort wealth. Still, a coherent concept for separating fiscal imbalance from aggregate redistribution is lacking in the GA literature. Without such a concept, comparison of sustainability indicators obtained for different years and countries is not unproblematic.

${ }^{22}$ Generational accounts close to zero might indicate strong redistribution across genders, i.e. intragenerational redistribution, basically due to intra-household transfers, see Jensen and Raffelhüschen (1997), but this is clearly not a necessary condition. 
particular, the generational accounts of generations born in the future are first evaluated on the basis of the status quo perspective. The sustainability gap at the base year, $S G_{t}$, is then given by

$$
S G_{t}=\sum_{i=t}^{\infty} G_{i}+B_{t}-\sum_{k=t-D}^{t} P_{t, t-k} G A_{k}-\sum_{k=t+1}^{\infty} P_{k, 0} G A_{k}^{f} .
$$

An interpretation of the sustainability gap is that it represents the present value of aggregated future primary deficits or surpluses given that the financial scope of the government was not restricted by the requirement to balance its intertemporal budget. In other words, as this cannot happen, the sustainability gap represents the intertemporal financial liabilities of the public sector (Raffelhüschen 1999) associated with continuation of current fiscal policy. These create a financing demand that eventually needs to be covered by adjusting the level of net taxes or net government purchases. This notion of public liabilities is different from the long-established concept of calculating the long-term spending commitments that are quasi property of economic agents, like interest payments and pension rights (Franco 1995). The concept of public liabilities expressed by (19) is only meaningful if interpreted as a reflection of the non-enforceable obligation of conforming to the fiscal balance rule.

Provided the sustainability gap is zero, it indicates long-term feasibility of fiscal policy in the sense of this concept. In this case, the net tax parameters set by current fiscal policy do not require that the government adjusts any generational account in order to satisfy the intertemporal budget constraint. In general, but not necessarily, this situation implies similar values of generational accounts (aside from discounting and growth effects) for the cohorts who are observed over the entire lifetime. That the status quo prediction leads to different lifetime net tax burdens on these generations, might only occur when some very long-term policy commitments are considered. ${ }^{23}$ Nevertheless, strictly speaking, the sustainability gap concept does not provide a test of the fiscal balance rule, but of the government's intertemporal budget constraint.

If the sustainability gap is positive (negative), the government needs to raise (reduce) net tax revenue over net government purchases at some point in time, which implies some

${ }^{23}$ It follows from the principles discussed in Section 3 that GA studies would in general not integrate these for a benchmark. But there are some examples in the GA literature where it is necessary to accurately design the impact of slowly maturing pension reforms, see Franco and Sartor (1999) and Cardarelli, Sefton, and Agulnik (2000). In general, the case might be more relevant for applications aiming at comparison of different policy strategies. 
redistribution across generations. While the sign of the sustainability gap is sufficient to give a hint at the direction of associated intergenerational redistribution, its size is difficult to judge for the lack of a benchmark. In the GA literature, there are different approaches to transform the sustainability gap into more accessible measures illustrating the dimension of the need for reform. The common idea behind these indicators, propagated by Jensen and Raffelhüschen (1997) and Auerbach and Kotlikoff (1999), is to express the financial demand of the sustainability gap in terms of standardized policy experiments with the property of calibrating the intertemporal budget.

A commonplace approach is to report the revenue need indicated by the sustainability gap in terms of a in terms of a macroeconomic variable of economic activity. Frequently this benchmark is current GDP, which has the advantage that the resulting indicator is immediately comparable with the familiar debt-to-GDP ratio. The outcome of such a comparison gives an indication to what extent future fiscal policy, which is still under control of decision makers, adds liabilities to current public debt, which already is a datum of fiscal policy.

However, the short term perspective on economic activity is somewhat inconsistent with the intertemporal focus of the GA method. A preferable way to report the sustainability gap at the macro level therefore is in terms of the present value aggregate of future yearly GDP. At least this allows to capture the response of national product to variations in the population or economic parameters. An indicator expressing the sustainability gap as a fraction of expected overall future GDP has a straightforward interpretation - it represents the constant share in national product by which the government needs to reduce the primary deficit in each year, in order to achieve fiscal sustainability. This amount might either be raised through a reduction in government purchases, or through extracting more net taxes from private agents. The projection of future GDP required for this indicator can be easily constructed referring to the stylized model of economic growth underlying the generational accounts. This means that aggregate output is linked to output per worker in the base year, which is yearly updated at the uniform growth rate $g$, and combined with the population forecast to find the macroeconomic aggregate.

An alternative set of indicators closer to the original GA concept translates the sustainability gap into fictive generational accounts. Conversion of the fiscal imbalance evaluated at the macro level requires to assume specific fiscal policies. On the one hand, the 
analyst has discretion about which generations bear the adjustment. As above, in order to highlight the distributional conflict between living and future generations, one might adjust the generational account of the prospective newborn only. An alternative would be to let all generations have a share in the adjustment. On the other hand, since the sustainability approach requires to evaluate all generational accounts explicitly, the analyst has to set the type of fiscal policy used to balance the intertemporal budget. For conceptual clarity, generational accountants normally rely on hypothetical policies. Typical examples are the assumptions that all taxes will be raised by a constant proportion, over all age groups and generations, or, that all transfers will be cut by a uniform proportion.

In technical terms, this approach demands to recalculate the generational accounts of those cohorts assumed to bear the adjustment on the basis of hypothetical payment levels at the individual level. Returning to the notation of Section 3, this requires to make the following replacement: $\tau_{i, j}^{\prime}=\theta \tau_{i, j}$, for all tax $(\tau>0)$ or transfer $(\tau<0)$ payments entering into the generational accounts and by assumption affected by the balancing policy. ${ }^{24}$ The adjustment factor $\theta$ has to be determined such that the sustainability gap evaluated on the basis of the reevaluated tax or transfer payments becomes zero. For many policy assumptions, it is possible to write down an analytical solution for $\theta$, starting from (19). In any case one can evaluate the balancing parameter using calibration.

The fiscal policy indicator approach yields several options of expressing the size of the intertemporal public liabilities. A first option is to simply report the size of the adjustment parameter $\theta$. Obviously, sustainable fiscal policy is indicated by $\theta=0$. A second option is to translate the adjustment at the micro level into the effected change in the corresponding macroeconomic tax or transfer rate. This is not adequate, however, if the policy change is assumed to affect only future generations considering that the aggregate effects will emerge only slowly over a long period. Given that the policy change affects all generations, one might evaluate the immediate change tax or transfer rate to GDP. A more informative indicator is given by the change in the aggregate present value of prospective payments relative to the aggregate discounted value of future GDP. The intertemporal perspective has the advantage to account for potential future changes in the tax base or national product.

${ }^{24}$ For an allocation of the adjustment to future generations, the range of the period-age combinations $(i, j)$ is constrained. 
A final strategy is to report the impact of the balancing policy change in terms of the corresponding generational accounts. If the adjustment spreads across all generations, one might report the change in the generational accounts for the generation born in the base year. In most applications, this change is representative for future generations, as the updated fiscal policy parameters are sustainable by construction. In contrast, if the balancing policy targets only future generations, one might indicate the existing intergenerational imbalance of fiscal policy by the relative change of generational accounts, i.e. the indicator $\pi$, or if that is not applicable, by the absolute change in lifetime net tax rates. However, these changes in general are not unique considering that the value of the balancing generational accounts is specific to the selected policy experiment. How this effect works is not obvious which seems to give an advantage to the two previous indicators whose policy dependency lays open.

A disadvantage common to the previous sustainability indicators based on fiscal policy experiments is that they are not exclusively a function of the sustainability gap, but also a function of the original structure of the government budget and of the underlying age profiles of payments. As a consequence, the values of fiscal policy indicators obtained are not fully comparable across time and across countries, even if they are obtained with a constant GA methodology. To obtain an indicator which is neural against variations in the actual structure of fiscal policy parameters, Bonin (2001) proposes to work with a counterfactual poll tax imposed on each head of the population in each period. Assuming that this policy starts in the base year, the proposed indicator, $L S_{t}$, is given by

$$
L S_{t}=\frac{S G_{t}}{\sum_{i=t}^{\infty} \sum_{j=0}^{D} P_{i, j}\left(\frac{1+g}{1+r}\right)^{i-t}} .
$$

To achieve straightforward interpretation, the poll tax rate is assumed to stay constant except for the constant rate of income growth at the individual level, and expressed in present value terms of the base period. This requires to adjust the number of heads in the population among whom the sustainability gap can be distributed by a growth-adjusted discount factor. The indicator (20) translates the sustainability gap into the value of a once and for all yearly lump-sum payment. The poll tax concept thereby also achieves neutrality of the fiscal sustainability indicator against variations in life expectancy. A disadvantage of the approach, however, is that it ignores variations in gross income.

To summarize, GA produces various indicators for an illustration of the long-term 
fiscal imbalance associated with current parameters of fiscal policy. None of them generates a perfect index of fiscal sustainability under all circumstances. Therefore, in a typical empirical application, generational accountants rely on more than one measure from their toolbox.

\section{General Equilibrium Considerations}

The application of time invariant growth and interest factors to construct the generational accounts ignores the connection between the individual net tax burden and gross factor income in the economy. The possibility of changing factor incomes might limit the empirical validity of the generational account measures. Two aspects are especially relevant to evaluate the generational distribution of fiscal burdens correctly - the impact of the demographic evolution on the macroeconomic development, and the impact of behavioral responses to this development and to necessary changes in fiscal policy on the equilibrium growth path of the economy. These factors might draw a wedge between the utility levels realized by different generations and net tax levels measured by generational accounts.

A tool of proper dynamic incidence analysis of fiscal policies which is well suited to integrate demographic trends are computable overlapping generations, general equilibrium models (OLG-GE models). A strategy of gauging the empirical validity of GA is to compare the variations of generational accounts obtained in these models with the measured variations in actual generational welfare. In case dynamic behavioral effects dominate utility changes, the GA approach to indicate generational redistribution by primary levied net taxes is inadequate. Making the comparison between GA and OLG-GE results, it is important, however, to account for a fundamental conceptual difference. GA results are usually obtained assuming constant policy which allows accumulation of a sustainability gap that is left at once to future generation, whereas GE simulations necessitate to respect the no-Ponzi game condition which leads to a gradual updating of fiscal policy parameters.

Therefore, the evidence for the indicator qualities of GA that can be gathered from this kind of literature remains somewhat inconclusive. Integrating GA into a general equilibrium framework with two overlapping generations, Raffelhüschen and Risa (1997) analyze the transition to a funded pension system as a policy response to a demographic aging shock. Their results support the hypothesis that changes of generational accounts 
are a bad measure for changes of generational welfare, since the impact of the demographic transition in pre-tax income dominates the direct tax effects. In contrast, the results of numerous simulations obtained by Fehr and Kotlikoff (1996) using the well-known Auerbach and Kotlikoff (1987) model with 55 generations, overall seem to support generational accounts as approximations of generational welfare, under the realistic condition that capital adjustment costs are small. According to their analysis of many stylized fiscal policies, the generational accounts mainly fail when the progressivity of net taxes is increased, and in small open economies, which are characterized by more short-term changes in factor returns.

In a reassessment of this study, (Börstinghaus and Hirte 2001) question these conclusion. They consider the fact that the assessment of GA by Fehr and Kotlikoff (1996) is based on the notion of changes in net tax liabilities along the trajectory to an intertemporally balanced budget and not on status quo generational accounts as a source of bias. To illustrate that generational accounts following the standard concept of GA might be a not so good shortcut for the incidence of fiscal policy, consider a reform cutting the average tax on labor income. In an OLG-GE model, this requires to raise some other tax (say the consumption tax) instantaneously to keep the intertemporal government budget in balance. Furthermore, since labor supply is endogenous, the income tax cut reducing disincentives generates an efficiency gain which gradually increases over time. Measures of cohort welfare obtained from an OLG-GE model therefore indicate that the reform is a burden on the first generations who cannot anticipate the consumption tax increase and do not yet experience the full benefit of the income tax cut, whereas later generations are better off because of the efficiency gain.

The GA measures, in contrast, only notice the income tax cut, which shows up in smaller generational accounts for the first generations, and in larger generational accounts for later generations if one makes the standard assumption of GA that the sustainability gap associated with the tax cut is not at all imposed on the living. Hence the results on generational fiscal burdens obtained by the GA and the OLG-GE approach seem to point into opposite directions. However, a major part of the discrepancy is not due to the fact that the latter allows behavioral responses. Rather, the comparison is biased since the analysis actually simulates two different policy schemes. In fact, evaluating the generational accounts on the basis of the same refunding assumptions as in the OLG-GE 
model, i.e. without the postponement of refunding to future generations, yields better approximations of cohort welfare.

For example, assume that the revenue need to balance a pay-as-you-go scheme in an economy hit ba demographic aging is covered by a reduction in transfer levels. Assuming that this policy is immediately implemented, this leads to a burden on current living generations. The generational accounts of the older living increase, to the benefit of the generational accounts of younger and future generations. The same effects are indicated evaluating generational welfare in an OLG-GE model, where it is amplified, however, by the efficiency gains associated with lower labor taxes relative to a defined benefit scenario. As a result, the gap between generational accounts and actual cohort welfare tends to increase over time, but except for some cohorts the GA measures are good approximation of fiscal incidence.

Nevertheless, as these considerations might not be relevant in specific applications faced by analysts, GA as a tool of fiscal policy analysis should in general be complemented by an assessment of predictions obtained in a OLG-GE framework. In any case, these will not be perfect either. The potential drawbacks are numerous. For example, the extent of capital deepening in an OLG-GE framework not only depends on perfect foresight of rational forward-looking agents, but varies depending on the assumptions made regarding the degree of altruism, bequest motives, labor supply formation, the working of technological progress, etc. All of these might affect the evolution of pre-tax factor income that is a driving force of cohort welfare as opposed to generational accounts. Furthermore, the obtained results might be substantially different depending on whether an OLG-GE model with exogenous growth (Kotlikoff et al. 2001) or with endogenous growth (Fougère and Mérette 2000) is analyzed.

Finally, a fundamentally unanswered question pushing the development of a recent literature is the extent to which demographic changes are exogenous to the economic evolution, or an endogenous economic process, see Becker et al. (1990) and Galor and Weil (2000). If fertility decisions are not totally exogenous, intergenerational transfers in the economy cannot be assessed in the standards fashion. Firstly, the dimension of private and public intergenerational redistribution is correlated with fertility. ${ }^{25}$ More

${ }^{25}$ Peters (1995) derives conditions for optimal fiscal policy in an endogenous growth model with endogenous fertility. Ab-io et al. (2003) discuss optimal pension policy when demographic transition is endogenous. 
importantly, as shown by Sinn (2000), the condition for a dynamic efficient economy that the interest rate exceeds the population growth rate, is not longer a benchmark for Pareto optimality. This result requires a reappraisal of the intertemporal government budget constraint fundamental to GA, but implies a potential of even larger bias in OLG-GE results obtained in an exogenous fertility setting.

To sum up, the predictions about the development of key economic parameters such as pre-tax factor prices in response to changes of demographic and fiscal policy parameters depends very much on the specification of the simulation model and in particular the set of variables that is allows to be endogenous. The current state of the literature in the fields of OLG-GE models recommends to use them as a complement, but not as an alternative to GA. In fact, GA appears as a relatively transparent if not perfectly accurate measurement technique that is half way between general equilibrium simulation methods and other forward-looking budgeting methods found in the literature, which typically adopt a more ad hoc and less comprehensive perspective focus on a specific aspect of future fiscal policy. On the one hand, the method systematically links the development of the entire primary budget to the development of the population, thus obtaining more accurate indicators for a potential sustainability gap associated with current fiscal policy. On the other hand, GA permits to transform measures of fiscal imbalance at the macro level into indicators for intergenerational income redistribution, namely generational accounts, that resemble those obtained from the more elaborate OLG-GE models. 


\section{References}

Abio, G., E. Berenguer, H. Bonin, J. Gil, and C. Patxot (2003): "Is the Deficit under Control? A Generational Accounting Perspetive on Fiscal Policy and Labour Market Trends in Spain," Investigaciones Economicas, 27(2), 309-341.

Abío, G., G. Mahieu, and C. Patxot (2003): "On the Optimality of PAYG Pension Systems in an Endogenous Fertility Setting," CES Working Paper No. 1050, Munich.

Ablett, J. (1996): "Generational Accounting - An Australian Perspective," Review of Income and Wealth, 42, 91-105.

(1997): "A Set of Generational Accounts for Australia: Baseyear 1994/95," The Economic and Labor Relations Review, 8, 90-109.

Ablett, J., and Z. Tseggai-Bocureziou (2000): "Lifetime Net Average Tax Rates in Australia since Federation," The Economic Record, 76, 139-151.

Altamiranda, M. (1999): "Argentina's Generational Accounts: Is the Convertibility Plan's Fiscal Policy Sustainable?," in Generational Accounting around the World, ed. by A. Auerbach, L. Kotlikoff, and W. Leibfritz, pp. 141-160. University of Chicago Press.

Altonji, J., F. Hayashi, and L. Kotlikoff (1997): "Parental Altruism and Inter Vivos Transfers: Theory and Evidence," Journal of Political Economy, 105, 1121-1166.

Auerbach, A. (1997): "Quantifying the Current U.S. Fiscal Imbalance," National Tax Journal, 50, 387-398.

Auerbach, A., J. Gokhale, and L. Kotlikoff (1991): "Generational Accounting: A Meaningful Alternative to Deficit Accounting," Tax Policy and the Economy, 5, 55-110. (1994): "Generational Accounting: A Meaningful Way to Evaluate Fiscal Policy," Journal of Economic Perspectives, 8(4), 73-94.

(1995): "Restoring Generational Balance in US Fiscal Policy: What will it Take?," Federal Reserve Bank Cleveland Economic Review, 31, 2-12.

Auerbach, A., J. Gokhale, L. Kotlikoff, and E. Steigum (1993): "Generational Accounting in Norway: Is Norway Overconsuming its Petroleum Wealth," Working Paper no 9305, Federal Reserve Bank of Cleveland.

Auerbach, A., and L. Kotlikoff (1987): Dynamic Fiscal Policy. Cambridge University Press, Cambridge.

(1999): "The Methodology of Generational Accounting," in Generational Accounting around the World, ed. by A. Auerbach, L. Kotlikoff, and W. Leibfritz, pp. 31-41. University of Chicago Press.

Auerbach, A., and P. Oreopoulos (2000): "The Fiscal Effect of U.S. Immigration: A Generational Accounting Perspective," Tax Policy and the Economy, 14, 123-156.

Baker, B., D. Besendorfer, and L. Kotlikoff (2002): "Intertempral State Budgeting," NBER Working Paper No. 9067, Cambridge. 
Balassone, F., and D. Franco (2001): "Assessing Fiscal Sustainability: A Review of Methods with a View to EMU," in Fiscal Sustainability, ed. by Bank of Italy, pp. 21-60.

Ball, L., D. Elmendorf, and G. Mankiw (1998): "The Deficit Gamble," Journal of Money, Credit and Banking, 30, 699-720.

Banks, J., R. Disney, and Z. Smith (2000): "What Can we Learn about Pension Reform from Generational Accounts for the UK?," The Economic Journal, 110, F575F597.

Barro, R. (1974): "Are Government Bonds Net Wealth," Journal of Political Economy, $82,1095-1117$.

Becker, G., K. Murphy, and R. Tamura (1990): "Human Capital, Fertility, and Economic Growth," Journal of Political Economy, 98, S12-S37.

Blanchard, O. (1990): "Suggestions for a New Set of Fiscal Indicators," OECD Working Paper no. 79, Paris.

Blanchard, O., and S. Fischer (1989): Lectures on Macroeconomics. MIT Press, Cambridge (MA), London.

Blanchard, O., and P. Weil (2001): "Dynamic Efficiency, the Riskless Rate and Debt Ponzi Games under Uncertainty," Advances in Macroeconomics, 1(2), http://www.bepress.com/bejm/advances/vol1/iss2/art3.

Blejer, M., and A. Cheasty (1991): "The Measurement of Fiscal Deficits: Analytical and Methodological Issues," Journal of Economic Literature, 24, 1644-1678.

Börstinghaus, V., And G. Hirte (2001): "Generational Accounting versus Compuatble General Equilibrium," Finanzarchiv, 58, 227-243.

Bonin, H. (2001): Generational Accounting - Theory and Application. Springer, Heidelberg.

Bonin, H., And K. Feist (2003): "Measuring Intergenerational Redistribution Inter Vivos: The Case of German Pension Reform," in Pension Reform: Redistribution and Risk, ed. by M. Weale, pp. 40-67. National Institute of Econnomic and Social Research.

Bonin, H., B. Raffelhüschen, and J. Walliser (2000): "Can Immigration Alleviate the Demographic Burden?," Finanzarchiv, 57(1), 1-21.

Bovenberg, A., and H. ter Rele (1999): "Government Finance and Ageing in the Netherlands," European Economy, Reports and Studies, pp. 133-147.

Buchanan, J. (1958): Public Principles of Public Debt. Richard Irwin, Homewood.

Buiter, W. (1997): "Generational Accounts, Aggregate Saving and Intergenerational Distribution," Economica, 64, 605-626.

Cardarelli, R., and J. Sefton (1999): "Rolling Back the UK Welfare State?," European Economy, Reports and Studies, pp. 193-206.

Cardarelli, R., J. Sefton, and P. Agulnik (2000): "The Pensions Green Paper: A Generational Accounting Perspective," The Economic Journal, 110, F598-610. 
Cardarelli, R., J. Sefton, and L. Kotlikoff (2000): "Generational Accounting in the UK," The Economic Journal, 110, F547-574.

Chamley, C. (1981): "The Welfare Costs of Capital Income Taxation in a Growing Economy," Journal of Political Economy, 89, 468-496.

Chouraqui, J., R. Hagemann, and N. Sartor (1990): "Indicators of Fiscal Policy: A Re-Examination," OECD Working Paper no. 78, Paris.

Cohen, D. (1985): "How to Evaluate the Solvency of an Indebted Nation," Economic Policy, 1, 139-156.

Congressional Budget Office (1995): "Who Pays and When? An Assessment of Generational Accounting," Washington D.C.,.

Dang, T., P. Antolin, And H. Oxley (2001): "Fiscal Implications of Ageing," OECD Working Paper Eco/WKP (2001) 31.

Diamond, P. (1965): "National Debt in a Neoclassical Growth Model," American Economic Review, 55, 1126-1150.

- (1996): "Generational Accounts and Generational Balance: An Assessment," National Tax Journal, 49, 597-607.

European Commission (2001): “The EU Economy - 2001 Review," European Economy, 73.

Fehr, H., And L. Kotlikoff (1996): "Generational Accounting in General Equilibrium," Finanzarchiv, 53, 1-27.

Feist, K., B. Raffelhüschen, R. Sullstrøm, and R. Vanne (1999): "Macroeconomic Turnabout and Intergenerational Redistribution in Finland," European Economy, Reports and Studies, pp. 163-178.

Feldstein, M. (1974): "Social Security, Induced Retirement, and Aggregate Capital Accumulation," Journal of Political Economy, 82, 905-926.

Fougère, M., And M. MÉrette (2000): "Population Ageing, Intergenerational Equity, and Growth: Analysis with an Endogenous Growth Overlapping-Generations Model," in Using Dynamic General Equilibrium Models for Policy Analysis, ed. by G. Harrison, pp. 325-361. Elsevier.

Franco, D. (1995): "Pension Liabilities - Their Use and Misuse in the Assessment of Fiscal Policies," European Commission Economic Papers no. 110, Brussels.

Franco, D., J. Gokhale, L. Guiso, L. Kotlikoff, and N. Sartor (1994): "Generational Accounting: The Case of Italy," in Savings and the Accumulation of Wealth: Essays on Italian Household and Government Saving Behavior, ed. by A. Ando, L. Guiso, and I. Visco, pp. 128-160. Cambridge University Press.

Franco, D., And N. Sartor (1999): "Italy: High Public Debt and Population Ageing," European Economy, Reports and Studies, pp. 117-132. 
Fullerton, D., And D. Rogers (1993): Who Bears the Income Tax Burden? Brookings, Washington.

Galor, O., And D. WeIL (2000): "Population, Technology and Growth from the Mathusian Regime to the Demographic Transition," American Economic Review, 90, 806-828.

Gokhale, J., And K. Smetters (2003): Fiscal and Generational Imbalances, New Budget Measures for New Priorities. AEI Press, Washington DC.

Gramlich, E. (1990): "Fiscal Indicators," OECD Working Paper no. 80, Paris.

Haveman, R. (1994): "Should Generational Accounts Replace Public Budgets and Deficits," Journal of Economic Perspectives, 8, 95-111.

Jensen, S., And B. Raffelhüschen (1997): "Generational and Gender-Specific Aspects of the Tax and Transfer System in Denmark," Empirical Economics, 22, 615-635.

Kakwani, N., and M. Krongaew (1999): "Thailand's Generational Accounts," in Generational Accounting around the World, ed. by A. Auerbach, L. Kotlikoff, and W. Leibfritz, pp. 413-446. University of Chicago Press.

Kotlikoff, L. (1979): "Social Security and Equilibrium Capital Intensity," Quarterly Journal of Economics, 93, 233-53.

(1988): "Intergenerational Transfers and Savings," Journal of Economic Perspectives, 2, 41-58.

(1993): "From Deficit Delusion to the Fiscal Balance Rule - Looking for a Sensible Way to Measure Fiscal Policy," Journal of Economics, 7(suppl.), 17-41.

Kotlikoff, L., K. Smetters, and J. Walliser (2001): "Finding a Way out of America's Demographic Dilemma," NBER Working Paper No. 8258, Cambridge.

Laitner, J., And T. Juster (1996): "New Evidence on Altruism: A Study of TIAACREF Retirees," American Economic Review, 86, 893-908.

Levy, J., And O. DoRÉ (1999): "Generational Accounting for France," in Generational Accounting around the World, ed. by A. Auerbach, L. Kotlikoff, and W. Leibfritz, pp. 239-276. University of Chicago Press.

McCarthy, T., and H. Bonin (1999): "EU Transfers and Demographic Dividends in Ireland," European Economy, Reports and Studies, pp. 101-116.

Mehra, R., And E. Prescott (1985): "The Equity Premium: A Puzzle," Journal of Monetary Economics, 15, 145-162.

Modigliani, F. (1961): "Long-Run Implications of Alternative Fiscal Policies and the Burden of the National Debt," The Economic Journal, 71, 730-755.

OECD (1998): "Economic Outlook," No. 64.

Office of Management and Budget (1994): "Analytical Perspectives," Budget of the United States Government, Fiscal Year 1995, Washington D.C. 
PAtxot, C., And H. Bonin (2004): "Integrating Backward and Forward Looking Techniques into Evaluation of Fiscal Sustainability," Mimeo, University of Barcelona.

Peters, W. (1995): "Public Pensions, Family Allowances and Endogenous Demographic Change," Journal of Population Economics, 8, 161-183.

Raffelhüschen, B. (1999): "Generational Accounting: Method, Data and Limitations," European Economy, Reports and Studies, pp. 17-28.

RAffelhüschen, B., And A. Risa (1997): "Generational Accounting and Intergenerational Welfare," Public Choice, 93, 149-163.

Ter Rele, H. (1997): "Generational Accounts for the Dutch Public Sector," CPB Netherlands Bureau for Economic Policy Analysis, Research Memorandum no. 135, The Hague.

Sinn, H.-W. (2000): "Why a Funded System is Useful and Why it is not Useful," International Tax and Public Finance, 7, 389-410.

Steigum, E., and C. Guersem (1999): "Generational Accounting and Depletable Natural Resources: The Case of Norway," in Generational Accounting around the World, ed. by A. Auerbach, L. Kotlikoff, and W. Leibfritz, pp. 369-396. University of Chicago Press.

Summers, L. (1981): "Capital Taxation and Capital Accumulation in a Life Cycle Growth Model," American Economic Review, 71, 533-544.

Wilhelm, M. (1996): "Bequest Behavior and the Effect of Heirs' Earnings: Testing the Altruistic Motive of Bequests," American Economic Review, 86, 874-892. 


\section{IZA Discussion Papers}

\begin{tabular}{|c|c|c|c|c|}
\hline No. & Author(s) & Title & Area & Date \\
\hline 976 & $\begin{array}{l}\text { J. D. Angrist } \\
\text { K. Lang }\end{array}$ & $\begin{array}{l}\text { Does School Integration Generate Peer Effects? } \\
\text { Evidence from Boston's Metco Program }\end{array}$ & 6 & $01 / 04$ \\
\hline 977 & $\begin{array}{l}\text { M. Corak } \\
\text { G. Lipps } \\
\text { J. Zhao }\end{array}$ & $\begin{array}{l}\text { Family Income and Participation in Post- } \\
\text { Secondary Education }\end{array}$ & 5 & $01 / 04$ \\
\hline 978 & $\begin{array}{l}\text { J. T. Addison } \\
\text { P. Portugal }\end{array}$ & $\begin{array}{l}\text { How Does the Unemployment Insurance System } \\
\text { Shape the Time Profile of Jobless Duration? }\end{array}$ & 3 & $01 / 04$ \\
\hline 979 & $\begin{array}{l}\text { M. Moreno } \\
\text { H. Ñopo } \\
\text { J. Saavedra } \\
\text { M. Torero }\end{array}$ & $\begin{array}{l}\text { Gender and Racial Discrimination in Hiring: A } \\
\text { Pseudo Audit Study for Three Selected } \\
\text { Occupations in Metropolitan Lima }\end{array}$ & 1 & $01 / 04$ \\
\hline 980 & $\begin{array}{l}\text { H. Ñopo } \\
\text { J. Saavedra } \\
\text { M. Torero }\end{array}$ & Ethnicity and Earnings in Urban Peru & 1 & $01 / 04$ \\
\hline 981 & H. Ñopo & Matching as a Tool to Decompose Wage Gaps & 1 & $01 / 04$ \\
\hline 982 & $\begin{array}{l}\text { I. Geishecker } \\
\text { H. Görg }\end{array}$ & $\begin{array}{l}\text { Winners and Losers: Fragmentation, Trade and } \\
\text { Wages Revisited }\end{array}$ & 2 & $01 / 04$ \\
\hline 983 & $\begin{array}{l}\text { D. Del Boca } \\
\text { M. Locatelli } \\
\text { D. Vuri }\end{array}$ & Child Care Choices by Italian Households & 3 & $01 / 04$ \\
\hline 984 & $\begin{array}{l}\text { W. Arulampalam } \\
\text { A. L. Booth } \\
\text { M. L. Bryan }\end{array}$ & $\begin{array}{l}\text { Are there Asymmetries in the Effects of Training } \\
\text { on the Conditional Male Wage Distribution? }\end{array}$ & 5 & $01 / 04$ \\
\hline 985 & $\begin{array}{l}\text { Š. Jurajda } \\
\text { H. Harmgart }\end{array}$ & When Are 'Female' Occupations Paying More? & 4 & $01 / 04$ \\
\hline 986 & $\begin{array}{l}\text { H. Brücker } \\
\text { P. Trübswetter }\end{array}$ & $\begin{array}{l}\text { Do the Best Go West? An Analysis of the Self- } \\
\text { Selection of Employed East-West Migrants in } \\
\text { Germany }\end{array}$ & 1 & $01 / 04$ \\
\hline 987 & $\begin{array}{l}\text { A. Ichino } \\
\text { G. Muehlheusser }\end{array}$ & $\begin{array}{l}\text { How Often Should You Open the Door? Optimal } \\
\text { Monitoring to Screen Heterogeneous Agents }\end{array}$ & 7 & $01 / 04$ \\
\hline 988 & M. Jansen & Can Job Competition Prevent Hold-Ups? & 7 & $01 / 04$ \\
\hline 989 & J. Wagner & $\begin{array}{l}\text { Are Young and Small Firms Hothouses for } \\
\text { Nascent Entrepreneurs? Evidence from German } \\
\text { Micro Data }\end{array}$ & 1 & $01 / 04$ \\
\hline 990 & $\begin{array}{l}\text { H. Bonin } \\
\text { C. Patxot }\end{array}$ & $\begin{array}{l}\text { Generational Accounting as a Tool to Assess } \\
\text { Fiscal Sustainability: An Overview of the } \\
\text { Methodology }\end{array}$ & 7 & $01 / 04$ \\
\hline
\end{tabular}

An updated list of IZA Discussion Papers is available on the center's homepage www.iza.org. 